\title{
Economics of a decision-support system for managing the main fungal diseases of winter wheat in the Grand-Duchy of Luxembourg
}

\author{
Moussa EL Jarroudi ${ }^{\mathrm{a}}$, Louis Kouadio ${ }^{\mathrm{b}}$, Marco Beyer ${ }^{\mathrm{c}}$, Jürgen Junk ${ }^{\mathrm{c}}$, Lucien Hoffmann ${ }^{\mathrm{c}}$, \\ Bernard Tychon $^{\mathrm{a}}$, Henri Maraite ${ }^{\mathrm{d}}$, Clive H. Bock ${ }^{\mathrm{e}}$, Philippe Delfosse ${ }^{\mathrm{c}, *}$ \\ a University of Liège, Arlon Campus Environnement, 185 Avenue de Longwy, Arlon B-6700, Belgium \\ ${ }^{\mathrm{b}}$ International Centre for Applied Climate Sciences, University of Southern Queensland, West Street, Toowoomba 4350, QLD, Australia \\ c Centre de Recherche Public-Gabriel Lippmann, 41 Rue du Brill, Belvaux L-4422, Luxembourg \\ d Université catholique de Louvain, Earth E Life Institute, Croix du Sud 2/3, Louvain-la-Neuve B-1348, Belgium \\ e USDA-ARS-SEFTNRL, 21 Dunbar Road, Byron, GA 31008, USA
}

\section{A R T I C L E I N F O}

\section{Article history:}

Received 11 August 2014

Received in revised form

21 November 2014

Accepted 22 November 2014

\section{Keywords:}

Crop protection

Sustainable agriculture

Fungicide profitability

Septoria leaf blotch

Wheat leaf rust

Fusarium head blight

\begin{abstract}
A B S T R A C T
We evaluated the cost effectiveness of a decision-support system (DSS) developed for assessing in real time the risk of progression of the main fungal diseases (i.e., Septoria leaf blotch, powdery mildew, leaf rusts and Fusarium head blight) of winter wheat in the Grand-Duchy of Luxembourg (GDL). The study was conducted in replicated field experiments located in four agricultural locations (representative of the main agro-ecological regions of the country) over a 10-year period (2003-2012). Three fungicide spray strategies were compared: a single DSS-based system and two commonly used spray practices in the GDL, a double- (2T) and a triple-spray (3T) treatment; there was also a non-treated control. In years with a high disease pressure, the DSS-based recommendation resulted in protection of the three upper leaves comparable to that achieved with the $2 \mathrm{~T}$ and $3 \mathrm{~T}$ treatments, with significant grain yield increases $(P>0.05)$ compared to the control (a 4 to $42 \%$ increase, depending on the site and year). Overall, the financial gain in treated plots compared with the control ranged from 3 to $16 \%$ at the study sites. Furthermore, in seasons when dry weather conditions precluded epidemic development, the DSS recommended no fungicide spray, reducing use of fungicide, and thus saving the cost of the product. The gain in yield for the 2T and 3T plots (compared with control) did not necessarily result in a financial gain during the duration of the experiment. This study demonstrates the potential advantages and profitability of using a DSS-based approach for disease management.
\end{abstract}

(c) 2014 Published by Elsevier B.V.

\section{Introduction}

Winter wheat (Triticum aestivum L.) is the most important grain crop grown in the Grand-Duchy of Luxembourg (GDL). The area under winter wheat in 2013 was 13,410 ha, with a total production of circa 86,433 metric tons (Ministère de l'Agriculture, 2014). Wheat protection in the GDL largely relies on early fungicide applications before appearance of severe symptoms that might reduce yield. Fungicides are routinely applied to control fungal diseases so as to prevent yield losses due to pathogens, to delay the senescence of the upper leaves or in some cases, to comply with the recommendations from the mill industry, thereby maximising economic returns. Generally, two to three fungicide treatments are applied during crop growth. The first spray is applied early

\footnotetext{
* Corresponding author. Tel.: +352 470261 442; fax: +352 470264.

E-mail address: delfosse@lippmann.lu (P. Delfosse).
}

in the season (during stem elongation), and aims to control early season diseases including powdery mildew (WPM, caused by Blumeria graminis DC. f. sp. tritici em. Marchal) and eyespot (caused by Pseudocercosporella herpotrichoides (Fron) Deighton). This fungicide application is often done in combination with herbicide or fertilizer applications. A second fungicide application typically aims to protect the flag leaf from Septoria leaf blotch (SLB, caused by Zymoseptoria tritici (Desm.) Quaedvlieg \& Crous). Since earlydeveloping epidemics of $Z$. tritici (approximately 245 days after sowing) are more destructive than late epidemics (with epidemic outbreaks around 270 days after sowing (approximately 270 days after sowing), an accurate forecast of infection for early epidemics is of particular concern (Beyer et al., 2012). A third application is sometimes applied at early flowering in order to protect the wheat crop against infection by Fusarium head blight (FHB, primarily caused by Fusarium graminearum Schwabe). Apart from these targeted fungal diseases, rusts [i.e., leaf rust (WLR) and stripe rust (WSR), caused by Puccinia triticina Roberge ex Desmaz. and $P$. 
striiformis Westend, respectively] have become of increasing economic concern over the last decade (El Jarroudi et al., 2009b, 2012b).

Decision-support systems (DSS) based on plant disease forecast models are increasingly used in integrated disease management programs (Knight, 1997; Moreau and Maraite, 2000; Verreet et al., 2000; Wegulo et al., 2011; El Jarroudi et al., 2014b). DSS help by limiting potentially harmful side effects of fungicide applications while ensuring economic benefits (Fabre et al., 2007; Shtienberg, 2013). Indeed, a major incentive in adoption of DSS by farmers is related to the cost advantages over conventional strategies (Wearing, 1988; Langvad and Noe, 2006; Fabre et al., 2007). Decision rules (i.e., tactical models) designed to provide farmers with binary advice ("treatment is needed" or "it is not worth the cost") are considered to be cornerstones for the implementation of DSS in integrated disease management programs (Hughes, 1999; Way and van Emden, 2000; McCown, 2002).

In Europe, including the GDL, the main fungicide groups used to control foliar fungal pathogens of wheat include the strobilurins and triazoles (EUROSTAT, 2007), both of which have a broad spectrum of activity. Chlorothalonil (a nitrile) has multi-site activity and good efficacy against the main pathogen Z. tritici (Beyer et al., 2011), and it is used in tank mixtures to delay the emergence of fungicide resistance. Recently, a new generation of succinate dehydrogenase inhibitors with excellent efficacy towards $Z$. tritici, but poor performance against F. graminearum (Dubos et al., 2013) and Fusarium culmorum (Pasquali et al., 2013), became available. A DSS based on different models for infection and progress was developed and validated for the main fungal diseases in the GDL [e.g., SLB (El Jarroudi et al., 2009a), WPM (El Jarroudi et al., 2011), and WLR (El Jarroudi et al., 2014a,b)]. This DSS determined (1) whether fungicide use was needed at all, and if so determined, (2) the best application time for a single treatment based upon the models' outputs and expert knowledge. Considering public awareness concerning environmental pollution (water quality, ecosystem sustainability, environmental pressure exerted by agriculture, climate change), and the increasing regulatory demand from national and international institutions and policy makers (national governments, non-governmental organisations, The European Commission, etc.), the assessment of the profitability of any crop protection strategy is of great importance. The main objective of this study was to assess the profitability of a single fungicide treatment recommended through the DSS, by protection provided to the three upper leaves of winter wheat, compared with conventional two or three spray fungicide regimes.

\section{Materials and methods}

\subsection{Overview of the decision-support system}

The DSS relies on (i) the mechanistic PROCULTURE model to simulate the emergence of the five last leaves as well as the availability of $Z$. tritici inoculum to infect those leaves (Moreau and Maraite, 1999, 2000; El Jarroudi et al., 2009a); (ii) an approach for predicting WLR and WSR infection and progress based on night weather variables (El Jarroudi et al., 2004, 2014a), and (iii) a model for simulating the progress of WPM (El Jarroudi et al., 2011). The inputs used for simulating the infection periods and progress of SLB, WLR, WSR and WPM are hourly meteorological data (i.e. maximum and minimum air temperatures, relative humidity, and rainfall) and observed disease incidence and severity. Meteorological variables were collected during the growing season using automatic meteorological stations located near each study site $(\leq 1 \mathrm{~km})$. The assessment of severity of fungal diseases was conducted weekly throughout the growing season. The need for and timing of the single fungicide spray using the DSS was based on the observed disease severity earlier in the cropping season [i.e., at growth stages (GS) 31-37 (Zadoks et al., 1974), or on the lower leaves L5-L4, L1 being the flag leaf], the susceptibility of the cultivars, past and forecasted weather conditions, and the predicted development of leaves based on the output of the PROCULTURE model. Furthermore, historical data (weather and disease incidence and severity) were used as a basis for similarity analysis to further evaluate the risk of severe disease development. Given a threshold level of observed disease severity (on the lower leaves) and weather conditions (actual and forecasted), an advice for fungicide treatment was taken and fungicides applied if required to protect the upper leaves. For example, for $5 \%$ emergence of L3 coinciding with SLB symptoms on L5 and a rainfall event, there is an increased risk that L3 will become diseased with SLB by full emergence. Thus a fungicide treatment for SLB is recommended if $75 \%$ of a latency period is completed combined with favourable weather conditions forecasted. When different fungal diseases are observed, the relative importance in severity of each of the diseases is first evaluated. A combined treatment (i.e. tank mixtures) is recommended for protecting the upper leaves against the predominant diseases, if required. For example, if SLB and WLR are observed on L5 at the emergence of L3, or moderate to high severity of SLB is observed on L5, associated with at least 5\% severity of WLR on L3, a tank mixture (triazoles and strobilurins in this case) is advised and should be applied to susceptible cultivars when forecasted weather is favourable for disease. If different diseases develop at different times, or there is a second outbreak, a risk assessment is made based on the field management practices (previous crop), the susceptibility of the cultivar to the disease, and historical examples, taking into account any effect of the remaining fungicide from the first application. If there is a high risk of the new disease outbreak affecting grain yield, a second fungicide treatment may be advised (thus in this situation two treatments will be recommended using the DSS).

\subsection{Experimental fields and data collection}

Experiments were carried out in fields of winter wheat at four locations in the GDL [Burmerange $\left(50^{\circ} 3^{\prime} \mathrm{N}, 6^{\circ} 1^{\prime} \mathrm{E}\right)$, Christnach $\left(49^{\circ} 47^{\prime} \mathrm{N}, 6^{\circ} 15^{\prime} \mathrm{E}\right)$, Everlange $\left(49^{\circ} 29^{\prime} \mathrm{N}, 6^{\circ} 19^{\prime} \mathrm{E}\right)$, and Reuler $\left.\left(50^{\circ} 11^{\prime} \mathrm{N}, 5^{\circ} 15^{\prime} \mathrm{E}\right)\right]$ during the $2003-2012$ growing seasons. Agronomic details of the trials are given in Table 1. The experimental design was a complete randomized block with four replicates (one replicate plot $=12 \mathrm{~m}^{2}$ ). Each fully randomized replicate block consisted of fungicide treated and non-treated (control) plots. The different fungicides applied, and the wheat GS when treated (each treatment was associated with a specific GS) are given in Table 2. The GS were assessed according to the Zadoks' decimal code (Zadoks et al., 1974). The fungicides used were commercially available and applied according to the manufacturer's recommendations. Crop management (sowing and harvest methods, fertilisation and weed control) was done as described previously (El Jarroudi et al., 2009a, 2012a).

During the 2003-2012 cropping seasons, two to three fungicide treatments were tested at each site (Table 2). They included a single DSS-based treatment, a double (2T) spray treatment, and a triple (3T) spray treatment. The $2 \mathrm{~T}$ and $3 \mathrm{~T}$ treatments represent common practice for fungicide use in winter wheat in the GDL (Guy Reiland, Personal comm.). Note that 3 T was included after the 2005 cropping season in order to protect the wheat crop against infection by FHB and was not tested during the 2003-2005 period.

The meteorological data, recorded at $10 \mathrm{~min}$ intervals, were automatically retrieved from a web-based database system (www.agrimeteo.lu) and processed using an automatic data processing chain for quality check and gap filling. As hourly intervals were needed for running the disease forecast models, the 10-min 
Table 1

Agronomic information for the winter wheat fields used at the four experimental sites in the Grand Duchy of Luxembourg, 2003 to 2012.

\begin{tabular}{|c|c|c|c|c|c|c|}
\hline Locations & Year & Cultivar & Sowing date & Previous crops & Nitrogen $\left(\mathrm{kg} \mathrm{Nha}^{-1}\right)$ & Harvest date \\
\hline \multirow[t]{10}{*}{ Burmerange } & 2003 & Dekan & 4 Oct. 2002 & Oilseed rape & 185 & 11 Jul. 2003 \\
\hline & 2004 & Cubus & 1 Oct. 2003 & Oilseed rape & 185 & 2 Aug. 2004 \\
\hline & 2005 & Cubus & 13 Oct. 2004 & Oilseed rape & 185 & 4 Aug. 2005 \\
\hline & 2006 & Cubus & 30 Sep. 2005 & Oilseed rape & 192 & 19 Jul. 2006 \\
\hline & 2007 & Cubus & 11 Oct. 2006 & Oilseed rape & 192 & 26 Jul. 2007 \\
\hline & 2008 & Cubus & 6 Oct. 2007 & Oilseed rape & 228 & 5 Aug. 2008 \\
\hline & 2009 & Cubus & 6 Oct. 2008 & Oilseed rape & 228 & 29 Jul. 2009 \\
\hline & 2010 & Cubus & 1 Oct. 2009 & Oilseed rape & 228 & 6 Aug. 2010 \\
\hline & 2011 & Cubus & 1 Oct. 2010 & Oilseed rape & 228 & 4 Aug. 2011 \\
\hline & 2012 & Cubus & 14 Oct. 2011 & Maize & 228 & 3 Aug. 2012 \\
\hline \multirow[t]{10}{*}{ Christnach } & 2003 & Flair & 2 Oct. 2002 & Oilseed rape & 200 & 23 Jul. 2003 \\
\hline & 2004 & Flair & 13 Oct. 2003 & Oilseed rape & 200 & 12 Aug. 2004 \\
\hline & 2005 & Rosario & 27 Oct. 2004 & Maize & 200 & 2 Aug. 2005 \\
\hline & 2006 & Flair & 12 Oct. 2005 & Maize & 200 & 25 Jul. 2006 \\
\hline & 2007 & Tommi & 12 Oct. 2006 & Maize & 200 & 26 Jul. 2007 \\
\hline & 2008 & Flair & 23 Oct. 2007 & Maize & 200 & 5 Aug. 2008 \\
\hline & 2009 & Boomer & 23 Oct. 2008 & Maize & 200 & 7 Aug. 2009 \\
\hline & 2010 & Cubus & 15 Oct. 2009 & Oilseed rape & 200 & 23 Aug. 2010 \\
\hline & 2011 & Event & 15 Oct. 2009 & Oilseed rape & 200 & 19 Aug. 2011 \\
\hline & 2012 & Matrix & 7 Oct. 2011 & Maize & 200 & 15 Aug. 2012 \\
\hline \multirow[t]{10}{*}{ Everlange } & 2003 & Achat & 4 Oct. 2002 & Oilseed rape & 165 & 19 Jul. 2003 \\
\hline & 2004 & Achat & 14 Oct. 2003 & Oilseed rape & 195 & 6 Aug. 2004 \\
\hline & 2005 & Akteur & 22 Oct. 2004 & Oilseed rape & 190 & 2 Aug. 2005 \\
\hline & 2006 & Achat & 10 Oct. 2005 & Fallow & 225 & 7 Aug. 2006 \\
\hline & 2007 & Achat & 10 Oct. 2006 & Pea & 195 & 26 Jul. 2007 \\
\hline & 2008 & Tommi & 8 Oct. 2007 & Fallow & 195 & 5 Aug. 2008 \\
\hline & 2009 & Privileg & 13 Oct. 2008 & Oilseed rape & 195 & 6 Aug. 2009 \\
\hline & 2010 & Achat & 15 Oct. 2009 & Oilseed rape & 195 & 7 Aug. 2010 \\
\hline & 2011 & Achat & 15 Oct. 2010 & Oilseed rape & 195 & 6 Aug. 2011 \\
\hline & 2012 & Achat & 18 Oct. 2011 & Oilseed rape & 195 & 5 Aug. 2012 \\
\hline \multirow[t]{10}{*}{ Reuler } & 2003 & Flair & 6 Nov. 2002 & Oilseed rape & 213 & 5 Aug. 2003 \\
\hline & 2004 & Bussard & 16 Oct. 2003 & Oilseed rape & 200 & 16 Aug. 2004 \\
\hline & 2005 & Flair & 5 Oct. 2004 & Oilseed rape & 200 & 13 Aug. 2005 \\
\hline & 2006 & Dekan & 13 Oct. 2005 & Maize & 200 & 8 Aug. 2006 \\
\hline & 2007 & Akteur & 7 Oct. 2006 & Maize & 200 & 3 Aug. 2007 \\
\hline & 2008 & Schamane & 10 Oct. 2007 & Oilseed rape & 200 & 14 Aug. 2008 \\
\hline & 2009 & Schamane & 10 Oct. 2008 & Oilseed rape & 200 & 18 Aug. 2009 \\
\hline & 2010 & Manager & 28 Oct. 2009 & Oilseed rape & 200 & 23 Aug. 2010 \\
\hline & 2011 & Arktis & 28 Oct. 2009 & Oilseed rape & 200 & 20 Aug. 2011 \\
\hline & 2012 & Arktis & 15 Oct. 2011 & Oilseed rape & 200 & 18 Aug. 2012 \\
\hline
\end{tabular}

measurements were resampled to provide an hourly resolution (Junk et al., 2008). In addition, from the beginning of the disease monitoring period, the forecasted weather conditions (over the following seven days) were provided weekly by the Centre de Recherche Public-Gabriel-Lippmann, Luxembourg.

Assessments of the main fungal diseases were made weekly from GS 29-30 to GS 85. Estimates of disease severity (\% of leaf area diseased) were made on the same 10 plants in the control plots throughout the growing season, and bi-weekly on 10 randomly selected plants in each of the treated plots after applying the DSS treatment. Disease estimates were made to minimize errors by training raters using standard area diagrams (James, 1971) and disease assessment software (DISTRAIN, Tomerlin and Howell, 1988), and ensuring the same raters assessed the same experiments in each season (El Jarroudi et al., 2014c).

\subsection{Analysis of the impact of fungicide sprays on grain yield}

The winter wheat was harvested in mid-July in southern Luxembourg (Burmerange) and in the beginning of August at the other sites (Table 1$)$. The marketable yield $\left(Y_{g}\right.$, the total weight of grain) for each plot was determined automatically during the harvest in the field using an automated reaper (Wintersteiger AG, Austria), which has an overall accuracy $\pm 100 \mathrm{~g}$. Humidity content $(H$, expressed in \%) of the grain was determined in the laboratory on a sample of $500 \mathrm{~g}$ for each plot. The net grain yield for each plot
$\left(Y_{n}\right)$ was calculated at $14 \%$ humidity (typical humidity percentage in marketed winter wheat in the GDL) as follows:

$Y_{n}=\frac{(1-H) Y_{g}}{0.86}$

For each cropping season we calculated the difference between the yields (average net grain yield of the four repetitions) of fungicide treatment (i.e., DSS-based, 2T and 3T) and the control.

\subsection{Assessment of the economic impact of different fungicide treatments}

The economic impact of the different fungicide treatments focused on analysis over the whole study period. Thus, the financial return of each of the fungicide treatment strategies, including that of the control, was calculated as follows:

$R_{n}=Y_{N} \times P-\left(F_{c}+A_{c}\right)$

where $R_{n}$ is the financial return ( $€ \mathrm{ha}^{-1}$ ); $Y_{N}$ refers to the average $Y_{n}$ of the four repetitions for a given treatment $\left(\mathrm{dth} \mathrm{h}^{-1}\right.$, $\left.1 \mathrm{dt} \mathrm{ha}^{-1}=0.1 \mathrm{tha}^{-1}\right) ; P$ is the wheat price $\left(€ \mathrm{dt}^{-1}\right) ; F_{C}$ is the fungicide cost $\left(€ \mathrm{ha}^{-1}\right)$, and $A_{c}$ is the field fungicide application cost (fixed at $15 € \mathrm{ha}^{-1}$ during the study period).

The financial gain was then determined as the difference between the financial return of a given fungicide treatment (DSSbased, 2T and 3T) and the control. Fungicide application and fungicide costs involved in the calculation of financial returns 
Table 2

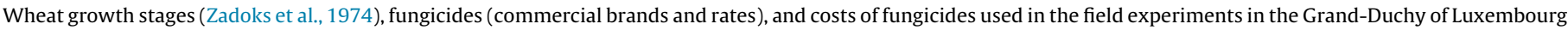
(2003-2012), and wheat prices over the same period.

\begin{tabular}{|c|c|c|c|c|c|c|}
\hline Year & Treatment $^{\mathrm{a}}$ & $\begin{array}{l}\text { Growth stage (GS) at } \\
\text { fungicide application }\end{array}$ & Fungicide $^{b}$ & $\begin{array}{l}\text { Fungicide } \\
\text { cost/unit }\left(€ \mathrm{ha}^{-1}\right)\end{array}$ & $\begin{array}{l}\text { Total fungicide } \\
\text { cost }\left(€ \mathrm{ha}^{-1}\right)\end{array}$ & $\begin{array}{l}\text { Wheat price } \\
\left(€ \mathrm{dt}^{-1}\right)\end{array}$ \\
\hline 2003 & $\begin{array}{l}\text { DSS-based } \\
2 \mathrm{~T}\end{array}$ & $\begin{array}{l}\mathrm{R}^{\mathrm{C}} \\
\text { GS } 31 \\
\text { GS } 59\end{array}$ & $\begin{array}{l}1.50 \mathrm{l} \mathrm{ha}^{-1} \text { Opera }^{\circledR} \\
1.50 \mathrm{l} \mathrm{ha}^{-1} \text { Sphere }^{\circledR} \\
1.00 \mathrm{l} \mathrm{ha}^{-1} \text { Horizon }^{\circledR}\end{array}$ & $\begin{array}{r}111.4 \\
97.3 \\
35.6\end{array}$ & $\begin{array}{l}111.4 \\
132.9\end{array}$ & 10.3 \\
\hline 2004 & $\begin{array}{l}\text { DSS-based } \\
2 \mathrm{~T}\end{array}$ & $\begin{array}{l}\text { GS } 31 \\
\text { GS } 59\end{array}$ & $\begin{array}{l}1.501 \mathrm{ha}^{-1} \text { Opera }^{\circledR} \\
0.75 \mathrm{l} \mathrm{ha}^{-1} \text { Opera }^{\circledR} \\
0.75 \mathrm{l} \mathrm{ha}^{-1} \text { Opera }^{\circledR}\end{array}$ & $\begin{array}{r}111.4 \\
55.7 \\
55.7\end{array}$ & $\begin{array}{l}111.4 \\
111.4\end{array}$ & 10.3 \\
\hline 2005 & $\begin{array}{l}\text { DSS-based } \\
2 \mathrm{~T}\end{array}$ & $\begin{array}{l}\mathrm{NR}^{\mathrm{d}} \\
\text { GS } 31 \\
\text { GS } 59^{\mathrm{a}}\end{array}$ & $\begin{array}{l}0.75 \mathrm{l} \mathrm{ha}^{-1} \text { Opera }^{\circledR} \\
0.75 \mathrm{l} \mathrm{ha}^{-1} \text { Opera }^{\circledR}\end{array}$ & $\begin{array}{l}55.7 \\
55.7\end{array}$ & 111.4 & 11.6 \\
\hline 2006 & $\begin{array}{l}\text { DSS-based } \\
2 \mathrm{~T} \\
3 \mathrm{~T}\end{array}$ & $\begin{array}{l}\text { R } \\
\text { GS } 31 \\
\text { GS } 59^{\mathrm{a}} \\
\text { GS } 31 \\
\text { GS } 37 \\
\text { GS } 59\end{array}$ & 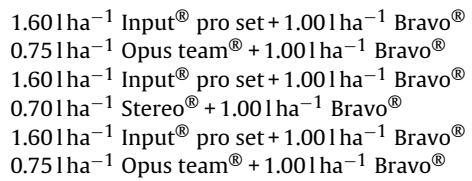 & $\begin{array}{l}81.9 \\
31.5 \\
81.9 \\
25.1 \\
81.9 \\
31.5\end{array}$ & $\begin{array}{l}81.9 \\
113.4 \\
138.5\end{array}$ & 15.3 \\
\hline 2007 & $\begin{array}{l}\text { DSS-based } \\
\text { 2T } \\
\text { 3T }\end{array}$ & $\begin{array}{l}\text { R } \\
\text { GS } 31 \\
\text { GS } 59^{\mathrm{a}} \\
\text { GS } 31 \\
\text { GS } 37 \\
\text { GS } 59\end{array}$ & 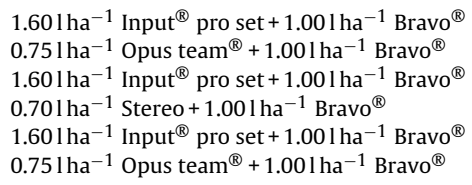 & $\begin{array}{l}81.9 \\
31.5 \\
81.9 \\
25.1 \\
81.9 \\
31.5\end{array}$ & $\begin{array}{l}81.9 \\
113.4 \\
138.5\end{array}$ & 26.0 \\
\hline 2008 & $\begin{array}{l}\text { DSS-based } \\
2 \mathrm{~T}\end{array}$ & $\begin{array}{l}\text { R } \\
\text { GS } 31 \\
\text { GS } 59^{a} \\
\text { GS } 31 \\
\text { GS } 37 \\
\text { GS } 59\end{array}$ & 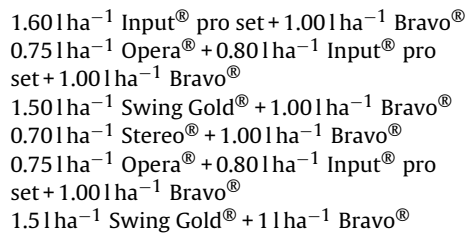 & $\begin{array}{r}81.9 \\
101.9 \\
58.5 \\
28.9 \\
101.9 \\
58.5\end{array}$ & $\begin{array}{l}81.9 \\
160.4\end{array}$ & 14.5 \\
\hline 2009 & $\begin{array}{l}\text { DSS-based } \\
2 \mathrm{~T}\end{array}$ & $\begin{array}{l}\text { R } \\
\text { GS } 31 \\
\text { GS } 59^{\mathrm{a}} \\
\text { GS } 31 \\
\text { GS } 37 \\
\text { GS } 59\end{array}$ & 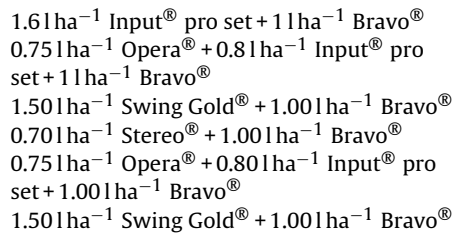 & $\begin{array}{r}81.9 \\
101.9 \\
58.5 \\
28.9 \\
101.9 \\
58.5\end{array}$ & $\begin{array}{l}81.9 \\
160.4\end{array}$ & 13.1 \\
\hline 2010 & $\begin{array}{l}\text { DSS-based } \\
2 \mathrm{~T}\end{array}$ & $\begin{array}{l}\text { NR } \\
\text { GS } 31 \\
\text { GS } 59^{\mathrm{a}} \\
\text { GS } 31 \\
\text { GS } 37 \\
\text { GS } 59\end{array}$ & 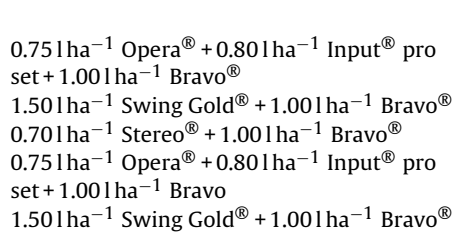 & $\begin{array}{r}101.9 \\
58.5 \\
28.9 \\
101.9 \\
58.5\end{array}$ & 189.3 & 20.0 \\
\hline 2011 & $\begin{array}{l}\text { DSS-based } \\
2 \mathrm{~T}\end{array}$ & $\begin{array}{l}\text { R } \\
\text { GS } 31 \\
\text { GS } 59^{\mathrm{a}} \\
\text { GS } 31 \\
\text { GS } 37 \\
\text { GS } 59\end{array}$ & 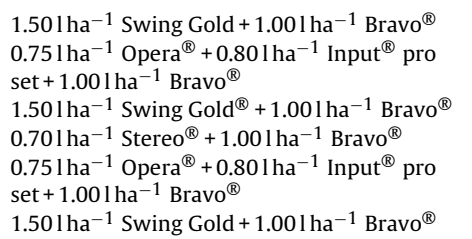 & $\begin{array}{r}58.5 \\
101.9 \\
\\
58.5 \\
28.9 \\
101.9 \\
\\
58.5\end{array}$ & $\begin{array}{l}58.5 \\
160.4\end{array}$ & 21.5 \\
\hline 2012 & $\begin{array}{l}\text { DSS-based } \\
2 \mathrm{~T}\end{array}$ & $\begin{array}{l}\text { R } \\
\text { GS } 31 \\
\text { GS } 59^{\mathrm{a}} \\
\text { GS } 31 \\
\text { GS } 37 \\
\text { GS } 59\end{array}$ & 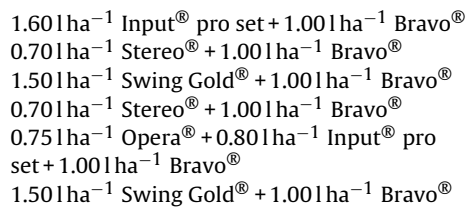 & $\begin{array}{r}81.9 \\
28.9 \\
58.5 \\
28.9 \\
101.9 \\
58.5\end{array}$ & $\begin{array}{l}81.9 \\
87.4 \\
189.3\end{array}$ & 24.4 \\
\hline
\end{tabular}

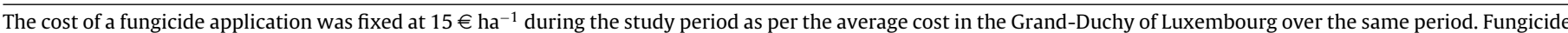
costs and wheat prices were communicated by Mr. Guy Reiland (Lycée Technique Agricole, Ettelbruck) based on the annual surveys of Luxembourgish farmers.

a DSS-based: Decision support system; 2T and 3T: double and triple fungicide treatments, respectively.

b The products Opera ${ }^{\circledR}$, Input ${ }^{\circledR}$ pro set, Bravo ${ }^{\circledR}$, Opus team ${ }^{\circledR}$, Stereo ${ }^{\circledR}$, and Swing Gold ${ }^{\circledR}$ contain the active ingredients epoxiconazole $(50 \mathrm{~g} / \mathrm{l})+$ pyraclostrobin $(133 \mathrm{~g} / \mathrm{l})$

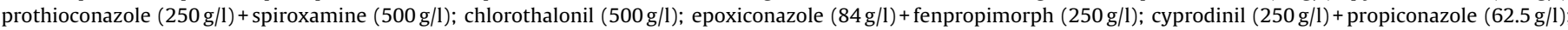
epoxiconazole $(50 \mathrm{~g} / \mathrm{l})+$ dimoxystrobine $(133 \mathrm{~g} / \mathrm{l})$, respectively.

c R: DSS-based treatment recommended. See details in Table 3 for each site.

d NR: No DSS-based treatment recommended. 


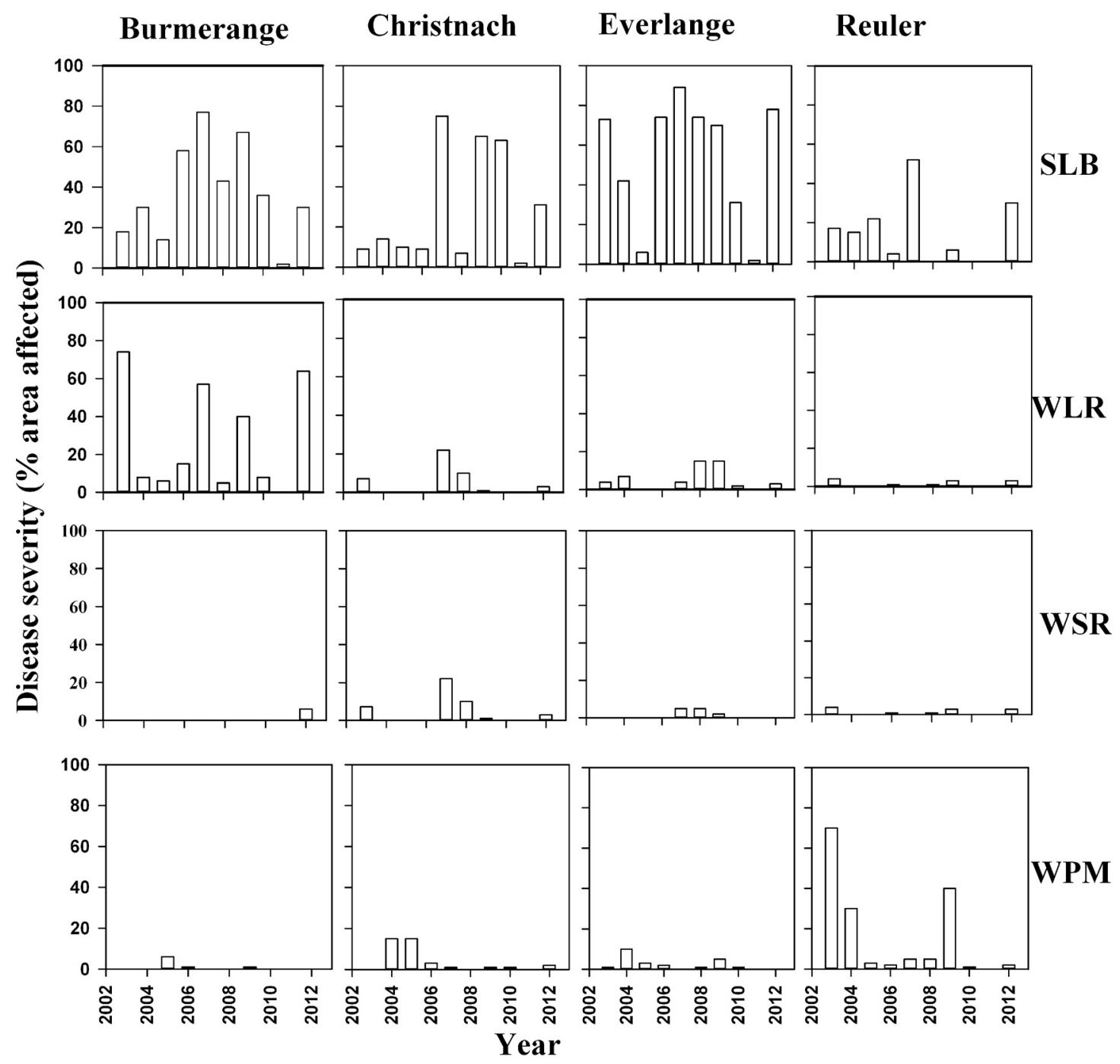

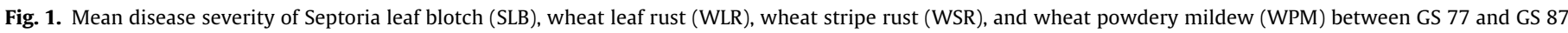

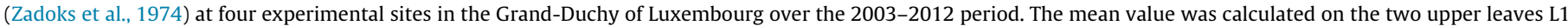
and L2, L1 being the flag leaf.

(Table 2) were provided by the Lycée Technique Agricole in Ettelbruck, GDL. Wheat prices (Table 2) were provided by the Administration des Services Techniques de l'Agriculture, GDL. In our analysis, machinery and machinery maintenance costs, as well as other costs related to fertilisation and weed control, were omitted because they could be considered the same across all plots.

\subsection{Statistical analysis}

All analyses were done in SAS ${ }^{\circledR}$ V9.2 (SAS Institute Inc., Cary, NC) or MS Excel (Microsoft, Redmond, WA). The replicate effects on grain yield and financial return at each location and year were subjected to analysis of variance (ANOVA) using the PROC GLM procedure. To assess the effects of year and fungicide treatment on winter wheat grain yield the PROC GLM procedure was run for the entire 2003-2012 period considering 3 years (2003-2005) of missing data for the 3T. This was found acceptable to summarize the results in Table 4 since independent analyses for the 2003-2005 and 2006-2012 periods yielded the same statistical conclusions (data not shown). PROC UNIVARIATE was used to determine the outliers based on residuals. Outliers were excluded based on residual values compared to the other values observed. The number of outliers removed from the analysis ranged from 0 to 2 depending on the experiment site. All outliers corresponded to low yield values from plots with harvested areas lower than the average (small harvested areas most often due to wind damage). Grain yield and financial gain were considered dependant variables, and year and fungicide treatment were independent variables. A Tukey's post hoc means separation test $(\alpha=0.05$ ) was used to compare the means. Any pairwise $P$-values $<0.05$ ( 2 -sided) were considered significant.

\section{Results}

\subsection{Fungal disease severities and fungicide spray recommendations}

Data (2003-2009 period) on the severity of fungal diseases were published previously by El Jarroudi et al. (2012b) and will not be described in detail. The severity of the main fungal diseases (i.e., SLB, WLR, WSR, and WPM) on the two upper leaves (in control plots) between GS 77 and GS 87 revealed that the disease pressure varied according to the disease involved, site and year (Fig. 1). Significant differences in severity among all diseases between the four sites and between years $(P<0.05)$ was observed. SLB was the most prevalent and important disease with the highest severity occurring in 2007 at all experimental sites (a mean of $70 \%$ leaf area 
Table 3

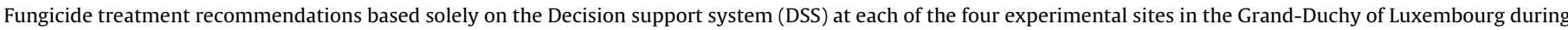
the 2003-2012 period (the growth stage and the date of the fungicide spray are indicated when the treatment is recommended).

\begin{tabular}{|c|c|c|c|c|c|c|c|c|c|c|}
\hline \multirow[t]{2}{*}{ Year } & \multicolumn{2}{|c|}{ Burmerange } & \multicolumn{2}{|c|}{ Christnach } & \multicolumn{2}{|c|}{ Everlange } & \multicolumn{2}{|l|}{ Reuler } & \multicolumn{2}{|c|}{$\begin{array}{l}\text { Total of } \\
\text { recommendations }\end{array}$} \\
\hline & Status & Date & Status & Date & Status & Date & Status & Date & $\mathrm{NR}^{\mathrm{a}}$ & $\mathrm{T}^{\mathrm{b}}$ \\
\hline 2003 & GS $59^{c}$ & 27 May & NR & & GS 59 & 2 June & GS 37 & 27 May & 1 & 3 \\
\hline 2004 & NR & & GS 45 & 2 June & GS 45 & 2 June & NR & & 2 & 2 \\
\hline 2005 & NR & & NR & & NR & & NR & & 4 & 0 \\
\hline 2006 & GS 37 & 11 May & NR & & GS 37 & 16 May & NR & & 2 & 2 \\
\hline 2007 & GS 45 & 15 May & GS 59 & 23 May & GS 37 & 3 May & GS 45 & 24 May & 0 & 4 \\
\hline 2008 & NR & & GS 37 & 20 May & NR & & GS 45 & 30 May & 2 & 2 \\
\hline 2009 & GS 45 & 27 May & GS 37 & 13 May & GS 37 & 13 May & NR & & 1 & 3 \\
\hline 2010 & GS 59 & 2 June & GS 40 & 2 June & GS 45 & 2 June & NR & & 1 & 3 \\
\hline 2011 & GS 69 & 9 June & GS 67 & 9 June & GS 67 & 9 June & NR & & 1 & 3 \\
\hline 2012 & GS 42 & 25 May & GS 40 & 25 May & GS 40 & 25 May & GS 37 & 25 May & 0 & 4 \\
\hline Total & & & & & & & & & 14 & 26 \\
\hline
\end{tabular}

a NR: no fungicide treatment recommended by the DSS.

b T: Treated (i.e. a single DSS-based fungicide treatment applied).

c DSS-based treatment recommended and applied at a specified plant growth stage (GS).

diseased recorded between GS 77 and GS 87 on the two upper leaves in 2007, Fig. 1). In addition, the most frequent incidence and severity of WLR was recorded namely at Burmerange; while Reuler had the lowest incidence and severity, but the highest incidence and severity of WPM. At the other sites the severity of WPM did not exceed 20\% leaf area diseased between GS 77 and GS 87 (Fig. 1). The severity of FHB (\% of infected grains by spike) was highest in 2007 and 2008 with a mean severity of $21 \%$ and $13 \%$ across the experimental sites, respectively (with a predominance at the Everlange and Christnach locations). FHB was not severe in the other seasons.

Over all 40 experiments (four sites $\times 10$ years), a single fungicide treatment was advised based on the DSS in 65\% of the time; conversely, $35 \%$ of the time no treatment was recommended (Table 3 ). At all sites receiving DSS advised treatment, even in years with severe SLB symptoms (2007), only the single fungicide application was made. However, in the 2005 cropping season no DSS-based treatment was recommended at any site despite the presence of fungal diseases at early crop development stages. These were not considered as threatening crop yield by the DSS because of a series of sequential forecasts for sunny and dry weather for the remaining of the 2005 cropping season. The 2T was not profitable in 2005 (see below in Section 3.4) and therefore the DSS, including weather forecast (Junk et al., 2008), appeared sensitive enough to tackle the relation between disease severity at early stages and risks of disease progress in terms of yield losses. Of the four sites, Reuler had the fewest occasions with DSS-advised treatment ( 6 out of 10 years, Table 3).

Overall, the latest timing of the DSS-based fungicide application was GS 59 at all sites over the 10-year period, except in 2011 when the DSS-based treatment was applied at GS 67-69 at Burmerange, Christnach and Everlange to protect the crop against SLB and an outbreak of WLR, and avoid the consequent effects on grain yield.

\subsection{Comparisons of grain yield during the 2003-2012 period}

The highest grain yield at each site was recorded in 2004 at Burmerange, Christnach and Everlange, and in 2005 at Reuler. The grain yield was lowest in 2012 at all sites. Overall, Burmerange had the highest grain yields: with $70 \%$ greater yield compared with the mean yield of all sites and years. Everlange and Reuler had the lowest annual yields (Fig. 2).

For each site, the effect of year and fungicide treatment on grain yield and financial return was analysed separately for (i) the years when the DSS recommended treatment (comparing the three fungicide treatment strategies DSS-based, 2T and 3T to the control), and (ii) years when it was not recommended (comparing the two fungicide treatment strategies $2 \mathrm{~T}$ and $3 \mathrm{~T}$ to the control).

Comparing all three treatment strategies, the ANOVA (Table 4) showed significant year and fungicide treatment main effects over the study period on grain yield at all locations $(P \leq 0.0001$ to $0.0003)$, with a significant year $\times$ fungicide treatment interaction only at Burmerange $(P=0.016)$. However, in years when no DSSbased treatment was recommended, the two-treatment strategies showed no fungicide treatment or interaction (year $\times$ fungicide treatment) effects on grain yield at any sites except Christnach (where only the fungicide treatment effect was significant, $P=0.015$ ). This result suggests the DSS is a highly effective tool for recommending fungicide sprays throughout the agricultural region of the GDL. The Reuler site was unique over the study period in years when no DSS-based treatment was recommended, as there was no significant effect of year, fungicide treatment or their interaction on grain yield $(P>0.05)$.

\subsection{Year by year comparisons of grain yield at each study location}

At all sites for years with fungicide treatment recommended by the DSS, a significant difference was observed in wheat grain yield between the control and the treated plots in 17 out of 26 situations $(P<0.05$, Table 5$)$. However, in some cropping seasons when the DSS-based recommendation was applied (Table 3), no difference was noted in the mean grain yield of the control and treated plots. These years were 2003 and 2010, 2008-2011, and 2009-2012 for Burmerange, Christnach, and Everlange, respectively. The comparisons among treated plots for years with DSS-based recommendation showed that most often there was no significant difference between the $2 \mathrm{~T}$ or $3 \mathrm{~T}$ treatment strategies at all sites, except Christnach in 2007 (where there was a significant difference between the DSS-based and 2T and 3T treated plots, $P<0.05$ ).

\subsection{Profitability of the decision support system (DSS)}

The overall ranges of gain in grain yield due to fungicide treatment were 1 to $81 \%, 3$ to $52 \%, 3$ to $28 \%$ and 2 to $45 \%$, respectively, for Burmerange, Christnach, Everlange and Reuler; the highest gains being recorded in the $3 \mathrm{~T}$ treated plots (Fig. 3). Irrespective of the site, the use of the DSS-based recommendation most often resulted in a grain yield gain over the control during the 10-year period, except at the Christnach site in 2011. Gains in grain yield using 
Control

DSS-based
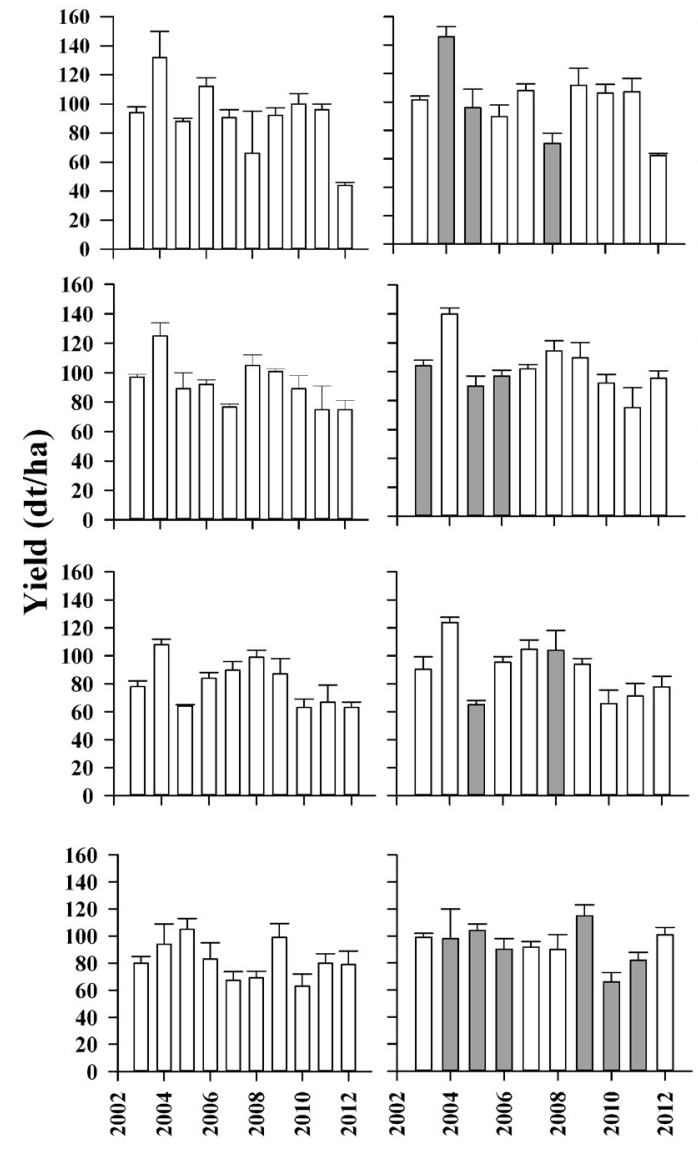

2T

3T
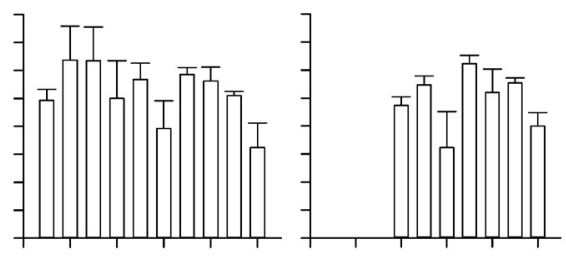

\section{Burmerange}

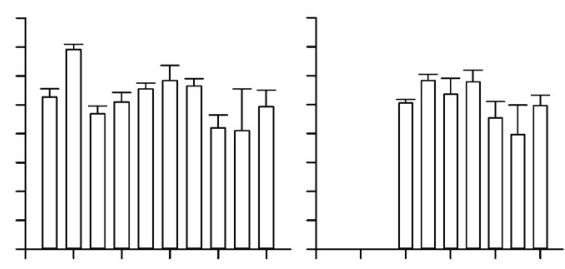

Christnach

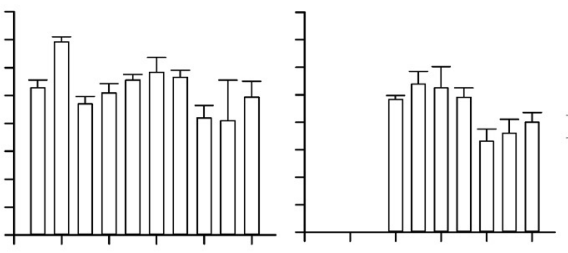

Everlange

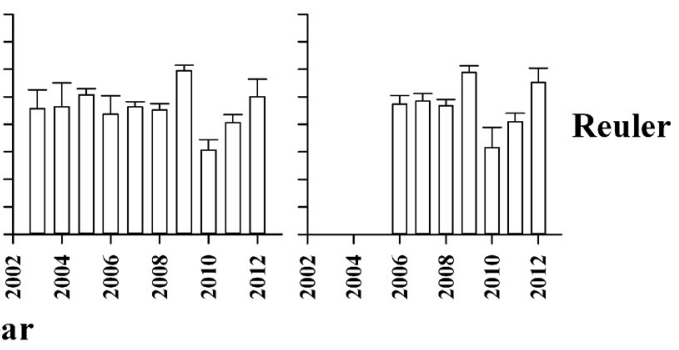

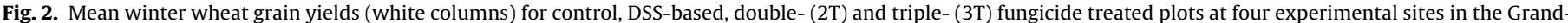

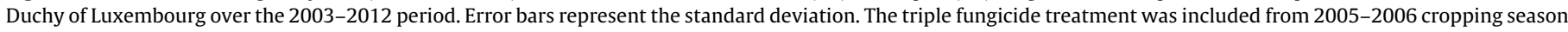

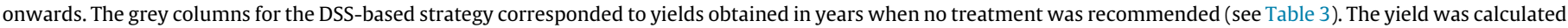
at $14 \%$ humidity. Note: $1 \mathrm{dt} \mathrm{ha}^{-1}=0.1 \mathrm{tha}^{-1}$.

the DSS-based recommendation varied from 6 to $42 \%, 3$ to $33 \%$, 5 to $23 \%$, and 23 to $37 \%$ on average at Burmerange, Christnach, Everlange and Reuler, respectively (Fig. 3). Similar trends were observed for the 2T and 3T treatments. However, the ANOVA using yield gain as a dependant variable revealed no significant differences between the three fungicide strategies at any site, except for Christnach in 2007 (significant difference between the DSSbased and $3 \mathrm{~T}$ treated plots, $P<0.05)$. In years when no DSS-based

\section{Table 4}

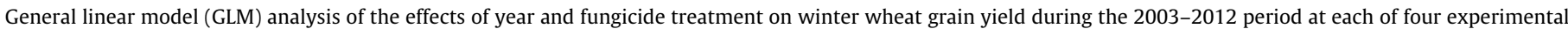

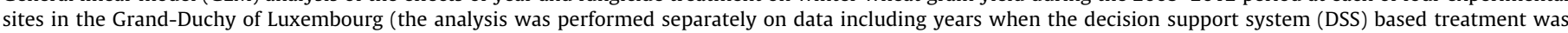
recommended and years when it was not).

\begin{tabular}{|c|c|c|c|c|c|c|c|}
\hline \multirow[t]{2}{*}{ Site } & \multirow[t]{2}{*}{ Effect } & \multicolumn{3}{|c|}{$\begin{array}{l}\text { Years when a DSS-based } \\
\text { treatment was recommended }\end{array}$} & \multicolumn{3}{|c|}{$\begin{array}{l}\text { Years when no DSS-based } \\
\text { treatment was recommended }\end{array}$} \\
\hline & & $\mathrm{DF}^{\mathrm{a}}$ & $F$-value & $\operatorname{Pr}>F^{b}$ & $\mathrm{DF}$ & $F$-value & $\operatorname{Pr}>F$ \\
\hline \multirow[t]{3}{*}{ Burmerange } & Year & 6 & 59.83 & $<0.0001$ & 2 & 12.13 & 0.0005 \\
\hline & Treatment & 3 & 23.45 & $<0.0001$ & 2 & 0.04 & 0.958 \\
\hline & Year $\times$ treatment & 16 & 2.11 & 0.016 & 2 & 1.01 & 0.383 \\
\hline \multirow[t]{3}{*}{ Christnach } & Year & 6 & 46.05 & $<0.0001$ & 2 & 5.15 & 0.01 \\
\hline & Treatment & 3 & 12.54 & $<0.0001$ & 2 & 5.77 & 0.015 \\
\hline & Year $\times$ treatment & 17 & 1.69 & 0.062 & 2 & 0.55 & 0.582 \\
\hline \multirow[t]{3}{*}{ Everlange } & Year & 7 & 75.35 & $<0.0001$ & 1 & 87.1 & $<0.0001$ \\
\hline & Treatment & 3 & 17.91 & $<0.0001$ & 2 & 1.09 & 0.361 \\
\hline & Year $\times$ treatment & 19 & 0.76 & 0.74 & 1 & 1.14 & 0.302 \\
\hline \multirow[t]{3}{*}{ Reuler } & Year & 3 & 7.65 & 0.0003 & 5 & 35.94 & 0.138 \\
\hline & Treatment & 3 & 33.64 & $<0.0001$ & 2 & 2.06 & 0.138 \\
\hline & Year $\times$ treatment & 8 & 0.65 & 0.73 & 8 & 1.13 & 0.358 \\
\hline
\end{tabular}

a Degrees of freedom.

b $\mathrm{Pr}>\mathrm{F}$ indicates the probability that the $F$-value for the model is significant. $P$-values $<0.05$ were considered significant. 
Table 5

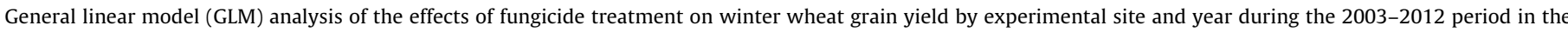

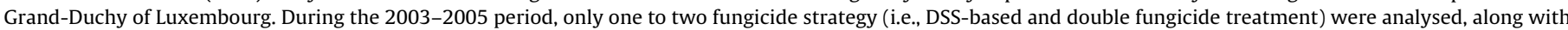
the control. The triple fungicide treatment was included from 2005 to 2006 cropping season onwards.

\begin{tabular}{|c|c|c|c|c|c|c|c|c|c|c|c|c|}
\hline \multirow{2}{*}{$\begin{array}{l}\text { Site } \\
\text { Year }\end{array}$} & \multicolumn{3}{|c|}{ Burmerange } & \multicolumn{3}{|c|}{ Christnach } & \multicolumn{3}{|c|}{ Everlange } & \multicolumn{3}{|c|}{ Reuler } \\
\hline & $\mathrm{DF}^{\mathrm{a}}$ & $F$-value & $\operatorname{Pr}>F^{\mathrm{b}}$ & $\mathrm{DF}$ & $F$-value & $\operatorname{Pr}>F$ & $\mathrm{DF}$ & $F$-value & $\operatorname{Pr}>F$ & $\mathrm{DF}$ & $F$-value & $\operatorname{Pr}>F$ \\
\hline 2003 & 2 & 1.56 & 0.262 & 1 & 8.94 & 0.024 & 2 & 8.72 & 0.008 & 2 & 4.62 & 0.042 \\
\hline 2004 & 1 & 0.96 & 0.371 & 2 & 18.30 & 0.0007 & 2 & 14.92 & 0.001 & 1 & 0.01 & 0.932 \\
\hline 2005 & 1 & 0.78 & 0.411 & 1 & 0.47 & 0.52 & 1 & 1.37 & 0.286 & 1 & 0.67 & 0.443 \\
\hline 2006 & 3 & 7.12 & 0.005 & 2 & 6.73 & 0.016 & 3 & 9.69 & 0.002 & 2 & 1.10 & 0.373 \\
\hline 2007 & 3 & 7.10 & 0.005 & 3 & 105.02 & $<0.0001$ & 3 & 5.71 & 0.012 & 3 & 30.70 & $<0.0001$ \\
\hline 2008 & 2 & 0.05 & 0.951 & 3 & 1.56 & 0.251 & 2 & 1.00 & 0.407 & 3 & 10.47 & 0.001 \\
\hline 2009 & 3 & 13.93 & 0.0003 & 3 & 3.20 & 0.063 & 3 & 3.32 & 0.057 & 2 & 10.62 & 0.004 \\
\hline 2010 & 3 & 0.90 & 0.469 & 3 & 0.51 & 0.685 & 3 & 0.50 & 0.689 & 2 & 0.05 & 0.949 \\
\hline 2011 & 3 & 4.87 & 0.019 & 3 & 0.10 & 0.956 & 3 & 0.22 & 0.879 & 2 & 0.15 & 0.859 \\
\hline 2012 & 3 & 5.64 & 0.030 & 3 & 9.09 & 0.002 & 3 & 2.91 & 0.078 & 3 & 7.00 & 0.006 \\
\hline
\end{tabular}

a Degrees of freedom.

b $\operatorname{Pr}>F$ indicates the probability that the $F$-value for the model is significant. $P$-values $<0.05$ were considered significant.

treatment was recommended at Burmerange (see Table 3 and indicated on Fig. 3), the $2 \mathrm{~T}$ treatment assured a yield gain only in 2005 and 2008, while the 3T treatment (2008) did not ensure a yield gain (Fig. 3). At Christnach and Everlange, all the 2T and 3T treatments led to a yield gain in those years when no DSSbased treatment was recommended. These gains compared to the control ranged from $3 \%$ to $11 \%$ for both sites in 2005 and 2008 . At Reuler no yield gain was observed in 2006 and 2010 with the $2 \mathrm{~T}$ treatment, and no noticeable gain (gain $\leq 3 \%$ ) was observed in 2010 and 2011 with the 3T treatment. Slight losses $(<2 \%)$ in yield compared with the control were observed in $2 \mathrm{~T}$ treated plots in 2004 at Burmerange, in 2010 at Christnach, and in 2005 and 2010
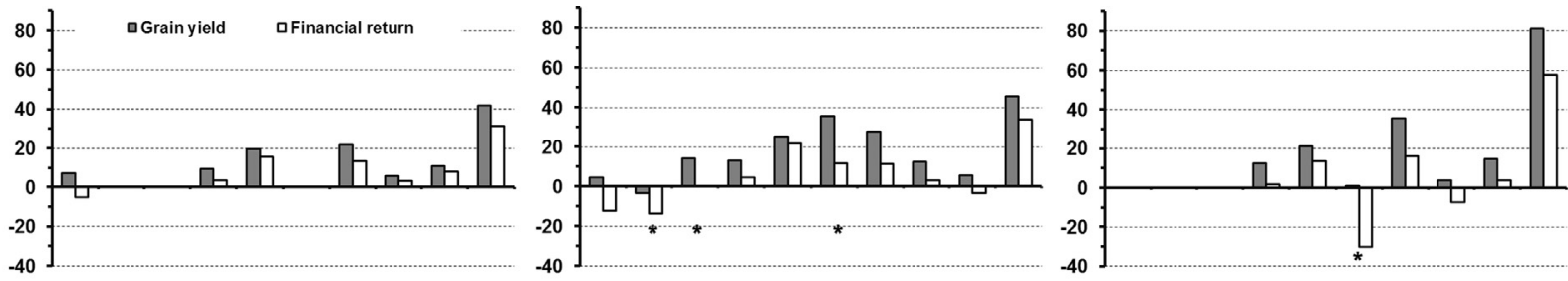

Burmerange
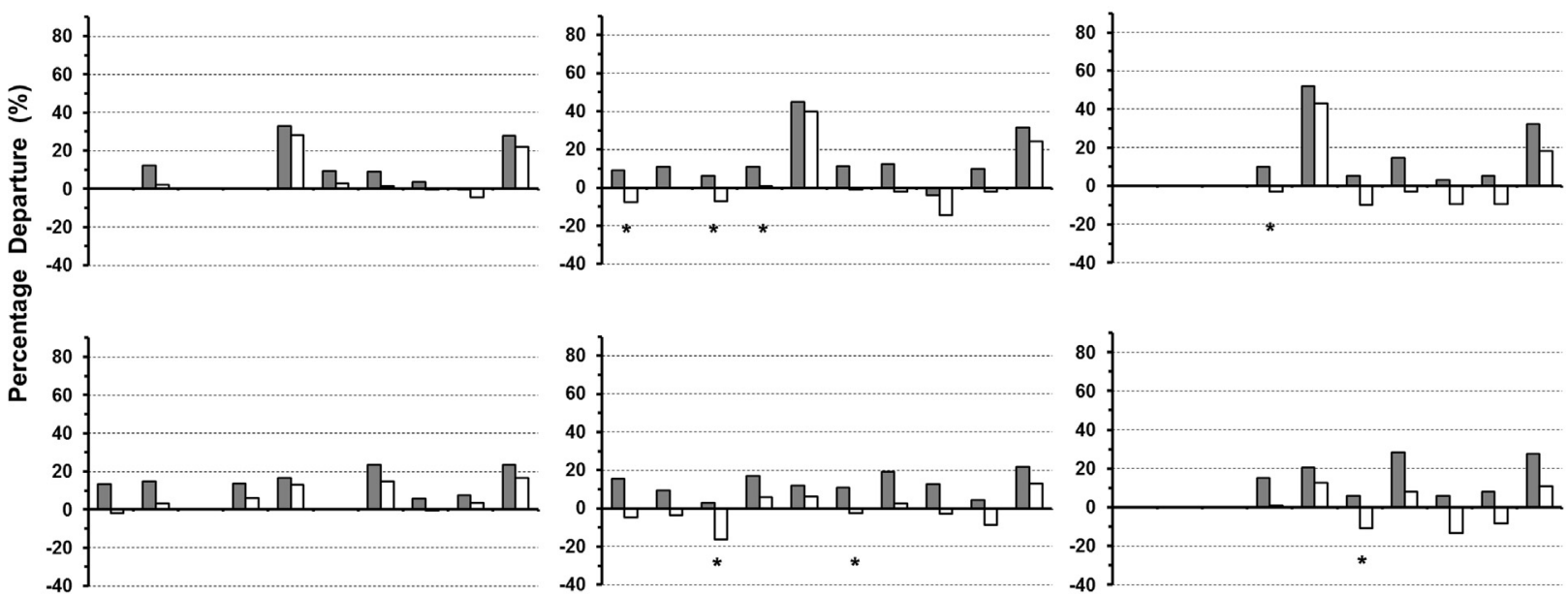

Christnach
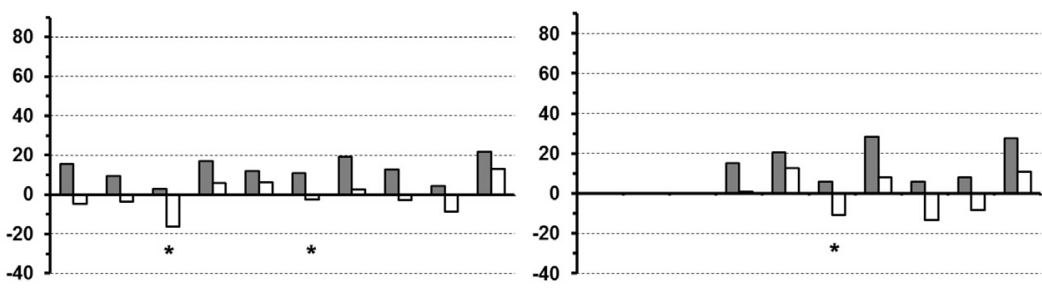

Everlange
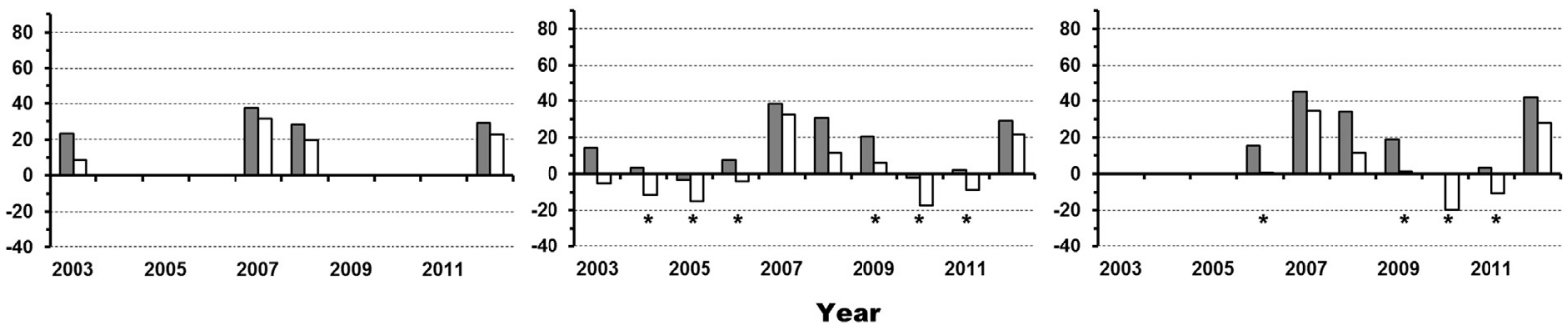

Reuler

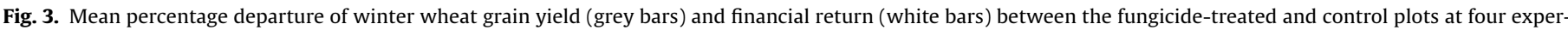

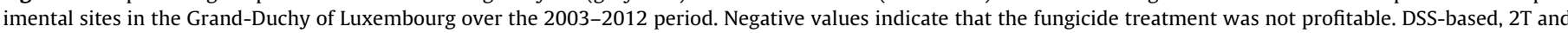

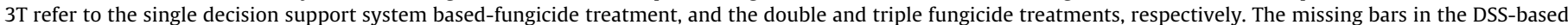

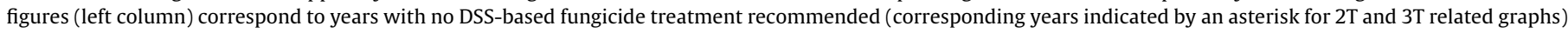
There were no 3T plots during the 2003-2005 growing seasons. 
at Reuler. The overall yield gains in treated plots at all sites during the study period suggest that those losses might be related to undefined factors linked to field-scale experiments such as wind damages. Additionally, in years when no DSS-based treatment was recommended, the grain yield in these DSS-based untreated plots did not differ significantly from that observed in the control plots $(P>0.05$, Fig. 2), as might be expected.

With respect to the financial return, the maximum gains over the study period were $\leq 58 \%, 43 \%, 17 \%$ and $34 \%$ for the Burmerange, Christnach, Everlange, and Reuler sites, respectively (Fig. 3). Regardless of the site, following the DSS-based recommendations resulted in a financial gain at all sites over the 2003-2012 period, except in 2011 at Christnach and in 2003 at Burmerange and Everlange. At Reuler, the DSS-based recommendations resulted in a financial gain in the four years when it was used (as did the $2 \mathrm{~T}$, except in 2003, and 3T treatments). Slight $(\leq 3 \%)$ to relatively important $(>10 \%)$ financial losses were observed in $2 \mathrm{~T}$ and $3 \mathrm{~T}$ treated plots at all sites during the study period, with the largest financial loss being 30\% recorded in 2008 for the $3 \mathrm{~T}$ plots at Burmerange. In years when no DSS-based treatment was recommended (see Table 3 and indicated on Fig. 3), the financial gain in fungicide treated plots was contrasted according to the year and site. Financial gains were observed only in 2009 at Reuler for the $2 \mathrm{~T}$ and $3 \mathrm{~T}$ treatments (a 1 to $5 \%$ increase, respectively, when compared with the control), and for the $2 \mathrm{~T}$ treatment at Christnach in 2006 and at Burmerange in 2008 ( $~ 1 \%$ and $12 \%$ increase, respectively, when compared with the control). An overall picture of the financial return at all sites during the study period revealed that in $33 \%$ to $60 \%$ and $30 \%$ to $70 \%$ of cases, there was a financial loss in the $2 \mathrm{~T}$ and $3 \mathrm{~T}$ treated plots, respectively. The gain in yield in those treated plots did not necessarily result in a financial gain. Particularly at Christnach and Everlange, in two to five years out of the seven years financial losses were recorded for 3T (Fig. 3). Such losses could be related to the application timing and/or its effectiveness in controlling the main diseases using a systematic scheduled spray approach, and possibly to the side-effects of their application (e.g. perturbation of reproductive organ development, alteration of nitrogen metabolism, etc.) eventually leading to a low yield gain and a financial loss.

\section{Discussion}

The European Union issued a directive (directive 2009/128/CE; Commission Européenne, 2009) that requires the member states to set up advice, training and scientific support for growers to ensure a healthy, sufficient and consistent food supply, which also limits potentially harmful side effects of pesticide applications. Optimising fungicide sprays by risk analysis and early warning systems is thus of great importance. The profitability of a crop protection strategy for diseases depends on various factors, namely the basic biological parameters of the pathosystem, the technical details of management tools, and historical and real-time information, so as to provide the basis for an effective and reliable forecasting system (Fabre et al., 2007). Although various disease forecast systems exist, the precise control time or economic injury threshold is not always clearly available (Shtienberg, 2013). In our study, we emphasized the grain yield gain and the financial return of a single fungicide treatment scheduled on the basis of a DSS. This analysis was achieved by a comparison with a control and with both a two and three fungicide spray approach (as usually applied by farmers in the GDL). The results showed that the DSS satisfactorily recommended none or a single fungicide treatment at each study site, regardless of geographical location or possible variability among the fungal diseases involved.

The single fungicide treatment recommended using the DSS most often resulted in efficient control of the major fungal diseases that was equal to that of the double or triple fungicide treatments.
Treating once but timely with an appropriate fungicide mix appears thus to be a judicious strategy to safeguard yield while minimising environmental damages. However, it may be speculated that the general success of the DSS-based single treatment observed during the studied period might be attributed to the predominance in this study of SLB which can be easily controlled by a timely single treatment (El Jarroudi et al., 2012b). In years with severe outbreaks of other important diseases such as WLR, FHB, a second fungicide application might be required to achieve an adequate crop protection.

When the weather conditions were not conducive to fungal infection or disease progress, no fungicide spray was recommended on the basis of the DSS, thus reducing further the use of chemical products that might be detrimental to the environment or human health. Multiple fungicide applications (two or three sprays) in such years did not provide significant gain in grain yields and often resulted in financial losses (Fig. 3). Several factors can affect the efficacy of wheat disease control (and thus profitability) using fungicides, in addition to the prevailing environmental conditions. The factors affecting profitability include cultural practices, cultivar resistance, other pest damage, key fungicide-related aspects (application timing and costs, effectiveness in controlling the diseases, type of fungicides), and the price of wheat (Ordish and Dufour, 1969; Carlson and Main, 1976). Plant physiological responses to fungicide exposure may also impact the profitability (Nason et al., 2007; Berdugo et al., 2012; Dias, 2012). Furthermore, fungicides might affect naturally occurring microflora (especially yeasts) on the phylloplane which might provide protection against pathogens, thus increasing the susceptibility of the plant to the pathogens (Bashi and Fokkema, 1977; Magan and Lacey, 1986; Mukerji et al., 1999; Rodgers-Gray and Shaw, 2001; Wachowska, 2005). In our analysis, the gain in yield in 2T and 3T treated plots did not necessarily result in a financial gain (see Fig. 3). In general, when factors that significantly reduce disease intensity, such as unfavourable environmental conditions, and when resistant cultivars prevail, the probability of a positive net return due to fungicide application is reduced. In our study, the probability of a positive net return was greatest when environmental conditions during the growing season favoured development of moderate to severe levels of fungal diseases. These conclusions support those of Guy et al. (1989) and Wegulo et al. (2011). In this respect, our results might provide useful information for operational fungal disease warning systems which will help reducing synthetic chemical fungicide sprays in winter wheat. Future studies may also test the DSS described herein for use in other cereal crops such as barley.

In the GDL, three types of farmers have been identified based on their method for making crop protection decisions (Guy Reiland, Personal comm.): (i) system-orientated farmers, (ii) experience-based farmers and (iii) advisory-orientated farmers. System-orientated farmers generally apply treatments following a partially fixed strategic plan (which is also used as a list for planning purchases of chemicals). They tend to manage big farms with specialised production and demand high levels of disease control. Experience-based farmers use a close, personal knowledge of each individual field (farm size low to medium) to base individual field-specific management choices, substituting detailed disease assessments with continuous more general observations of their fields. Advisory-orientated farmers contract their decisionmaking out to an advisor, and give higher priority to operations other than growing crops (generally livestock management). None of these groups of farmers have been prepared to perform detailed field-specific assessments in order to adjust the inputs according to the need in specific fields (Langvad and Noe, 2006). Thus, despite DSS systems based on in-season fungal diseases monitoring being a potentially useful, valuable and practical option, significant fractions of growers are not using them. Since 2004, 
warning bulletins (based on the DSS involved in this study) have been issued weekly throughout the growing season in the GDL so as to provide information to growers on the need for fungicide sprays and fungal diseases control. These bulletins are available in the GDL through various websites (http://www.centralpaysanne.lu, http://www.agrimeteo.lu, http://www.lwk.lu). The results presented in this study demonstrate the potential advantages to disease management and profitability of using this sort of DSS based approach. They also emphasize the need for a continued awareness of the wheat production sector on the actual requirement for crop protection through chemical fungicides.

\section{Acknowledgements}

This research was funded by the Ministry of Higher Education and Research of the Grand-Duchy of Luxembourg and the Administration des Services Techniques de l'Agriculture through the successive SINTAMA, MACRY and SENTINELLE projects. We extend our gratitude to Guy Reiland (Lycée Technique Agricole, Ettelbruck) for the valuable information about Luxembourgish cereals crop management. We are also grateful to Abdeslam Mahtour, Christophe Mackels, Virginie Schyns, Bertrand Martin, Farid Traoré, Michel Noel, Frédéric Giraud, Carine Vrancken, Friederike Pogoda, Guy Mirgain, Marc Kails and Alexandre Nuttens for their technical support, and Michel Santer, Marielle Lecomte, Laurent Pfister, and Jean-François Iffly for the meteorological data. We also thank the two anonymous reviewers for their valuable comments.

\section{References}

Bashi, E., Fokkema, N.J., 1977. Environmental factors limiting growth of Sporobolomyces roseus, an antagonist of Cochliobolus sativus, on wheat leaves. Trans. Br. Mycol. Soc. 68, 17-25.

Berdugo, C.A., Steiner, U., Dehne, H.W., Oerke, E.C., 2012. Effect of bixafen on senescence and yield formation of wheat. Pestic. Biochem. Physiol. 104, 171-177.

Beyer, M., El Jarroudi, M., Junk, J., Pogoda, F., Dubos, T., Görgen, K., Hoffmann, L., 2012. Spring air temperature accounts for the bimodal temporal distribution of Septoria tritici epidemics in the winter wheat stands of Luxembourg. Crop Prot. 42, 250-255.

Beyer, M., Kiesner, F., Verreet, J.-A., Klink, H., 2011. Fungicide sensitivity of Septoria tritici field isolates is affected by an interaction between fungicidal mode of action and time. J. Plant Pathol. 93, S1.7-S1.13.

Carlson, G.A., Main, C.E., 1976. Economics of disease loss management. Annu. Rev. Phytopathol. 14, 381-403.

Commission Européenne, 2009. Directive 2009/128/CE du Parlement Européen et du Conseil du 21 octobre 2009 instaurant un cadre d'action communautaire pour parvenir à une utilisation des pesticides compatible avec le développement durable. Journal Officiel de l'Union Européenne, Available at $\langle$ http://eur-lex. europa.eu/LexUriServ/LexUriServ.do?uri=OJ:L:2009:309:0071:0086:FR:PDF> (verified July 20, 2013), pp. L309/71-L309/86.

Dias, M.C., 2012. Phytotoxicity: an overview of the physiological responses of plants exposed to fungicides. J. Bot. 2012, http://dx.doi.org/10.1155/2012/135479.

Dubos, T., Pasquali, M., Pogoda, F., Casanova, A., Hoffmann, L., Beyer, M., 2013. Differences between the succinate dehydrogenase sequences of isopyrazam sensitive Zymoseptoria tritici and insensitive Fusarium graminearum strains. Pestic. Biochem. Physiol. 105, 28-35.

El Jarroudi, M., Delfosse, P., Maraite, H., Hoffmann, L., Tychon, B., 2009a. Assessing the accuracy of simulation model for Septoria leaf blotch disease progress on winter wheat. Plant Dis. 93, 983-992.

El Jarroudi, M., Giraud, F., Delfosse, P., Beyer, M., Hoffmann, L., Maraite, H., Tychon, B., 2011. Site-specific monitoring for disease forecasting in winter wheat. J. Plant Pathol. 93, S1.19-S11.20.

El Jarroudi, M., Giraud, F., Vrancken, C., Junk, J., Tychon, B., Hoffmann, L., Delfosse, P., 2009b. First report of wheat leaf rust in the Grand Duchy of Luxembourg and the progress of its appearance over the 2003-2008 period. Plant Dis. 93, 971.

El Jarroudi, M., Kouadio, L., Bertrand, M., Curnel, Y., Giraud, F., Delfosse, P., Hoffmann, L., et al., 2012a. Integrating the impact of wheat fungal diseases in the Belgian crop yield forecasting system (B-CYFS). Eur. J. Agron. 40, $8-17$.

El Jarroudi, M., Kouadio, L., Delfosse, P., Giraud, F., Junk, J., Hoffmann, L., Maraite, H., et al., 2012b. Typology of the main fungal diseases affecting winter wheat in the Grand Duchy of Luxembourg. J. Agri. Sci. Technol. 2, 1386-1399.

El Jarroudi, M., Kouadio, L., Delfosse, P., Tychon, B., 2014a. Brown rust disease control in winter wheat: I. Exploring an approach for disease progression based on night weather conditions. Environ. Sci. Pollut. Res. 21, 4797-4808.
El Jarroudi, M., Kouadio, L., Giraud, F., Delfosse, P., Tychon, B., 2014b. Brown rust disease control in winter wheat: II. Exploring the optimization of fungicide sprays through a decision support system. Environ. Sci. Pollut. Res. 21, 4809-4818.

El Jarroudi, M., Kouadio, L., Mackels, C., Tychon, B., Delfosse, P., Bock, C.H., 2014c A comparison between visual estimates and image analysis measurements to determine Septoria leaf blotch severity in winter wheat. Plant Pathol. http://dx.doi.org/10.1111/ppa.12252 (n/a-n/a).

El Jarroudi, M., Tychon, B., Maraite, H., Hoffmann, L., Touré, S., 2004. Use of the Monte Carlo method for evaluating the meteorological parameters which favour the epidemic of the yellow rust in the Grand Duchy of Luxembourg. In: Jacobsen, S.E., Jensen, C.R., Porter, J.R. (Eds.), Proceedings of the VIII ESA Congress European Agriculture in a global context. 11-15 July 2004, Copenhagen, Denmark, pp. 83-84.

EUROSTAT, 2007. The use of plant protection products in the European Union. Data 1992-2003. In: Eurostat Statistical Books, 2007 ed. European Commission, Office for Official Publications of the European Communities, Luxembourg.

Fabre, F., Plantegenest, M., Yuen, J., 2007. Financial benefit of using crop protection decision rules over systematic spraying strategies. Phytopathology 97, 1484-1490.

Guy, S.O., Oplinger, E.S., Wiersma, D.W., Grau, C.R., 1989. Agronomic and economic response of winter wheat to foliar fungicides. J. Prod. Agric. 2, 68-73.

Hughes, G., 1999. Sampling for decision making in crop loss assessment and pest management: introduction. Phytopathology 89, 1080-1083.

James, W.C., 1971. An illustrated series of assessment keys for plant diseases, their preparation and usage. Can. Plant Dis. Surv. 51, 39-65.

Junk, J., Görgen, K., El Jarroudi, M., Delfosse, P., Pfister, L., Hoffmann, L., 2008. Operational application and improvements of the disease risk forecast model PROCULTURE to optimize fungicides spray for the Septoria leaf blotch disease in winter wheat in Luxembourg. Adv. Sci. Res. 2, 57-60.

Knight, J.D., 1997. The role of decision support systems in integrated crop protection. Agric. Ecosyst. Environ. 64, 157-163.

Langvad, A.M. Noe, E., 2006. (Re-)innovating tools for decision-support in the light of farmers' various strategies. In: Langeveld, H., Röling, N. (Eds.), Changing European Farming Systems for a Better Future-New Visions for Rural Areas. Wageningen Academic Publishers, Wageningen, The Netherlands, pp. 335-339.

Magan, N., Lacey, J., 1986. The phylloplane microflora of ripening wheat and effect of late fungicide applications. Ann. Appl. Biol. 109, 117-128.

McCown, R.L., 2002. Changing systems for supporting farmers' decisions: problems, paradigms, and prospects. Agric. Syst. 74, 179-220.

Ministère de l'Agriculture, 2014. Production of Crops from Arable Land and Fodder Production. Service d'Economie Rurale, Grand-Duche de Luxembourg 〈http://www.ser.public.lu/statistics/crop_production/mengen_marktfruchtbau. pdf $\rangle$ (Verified March 29, 2014)

Moreau, J.M., Maraite, H., 1999. Integration of knowledge on wheat phenology and Septoria tritici epidemiology into a disease risk simulation model validated in Belgium. Aspects Appl. Biol. 55, 1-6.

Moreau, J.M., Maraite, H., 2000. Development of an interaction decision-support system on a web site for control of Mycosphaerella graminicola in winter wheat. Bull. OEPV/EPPO 30, 161-163.

Mukerji, K.G., Chamola, B.P., Upadhyay, R.K., 1999. Biotechnological Approaches in Biocontrol of Plant Pathogens. Kluwer Academic/Plenum Publishers, New York, NY, pp. 255.

Nason, M.A., Farrar, J., Bartlett, D., 2007. Strobilurin fungicides induce changes in photosynthetic gas exchange that do not improve water use efficiency of plants grown under conditions of water stress. Pest Manage. Sci. 63, 1191-1200.

Ordish, G., Dufour, D., 1969. Economic bases for protection against plant diseases. Annu. Rev. Phytopathol. 7, 321-327.

Pasquali, M., Spanu, F., Scherm, B., Balmas, V., Hoffmann, L., Hammond-Kosack, K.E., Beyer, M., et al., 2013. FcStuA from Fusarium culmorum controls wheat foot and root rot in a toxin dispensable manner. PLoS One 8, e57429.

Rodgers-Gray, B.S., Shaw, M.W., 2001. The effect of incorporating straw or manure into the soil on the natural microflora of winter wheat. Plant Pathol. 50, 537-545.

Shtienberg, D., 2013. Will decision-support systems be widely used for the management of plant diseases? Annu. Rev. Phytopathol. 51, 1-16.

Tomerlin, J.R., Howell, A., 1988. Distrain: a computer program for training people to estimate disease severity on cereal leaves. Plant Dis. 72, 455-459.

Verreet, J.A., Klink, H., Hoffmann, G.M., 2000. Regional monitoring for disease prediction and optimization of plant protection measures: the IPM wheat model. Plant Dis. 84, 816-826.

Wachowska, U., 2005. The role of pesticides in the development of populations of microorganisms colonizing the leaves of winter wheat. Pol. J. Environ. Stud. 14 95-102.

Way, M.J., van Emden, H.F., 2000. Integrated pest management in practice-pathways towards successful application. Crop Prot. 19, 81-103.

Wearing, C.H., 1988. Evaluating the IPM implementation process. Annu. Rev. Entomol. 33, 17-38.

Wegulo, S.N., Zwingman, M.V., Breathnach, J.A., Baenziger, P.S., 2011. Economic returns from fungicide application to control foliar fungal diseases in winter wheat. Crop Prot. 30, 685-692.

Zadoks, J.C., Chang, T.T., Konzak, C.F., 1974. A decimal code for the growth stages of cereals. Weed Res. 14, 415-421. 